\title{
Antimicrobial and Antioxidative Activities of Bioactive Constituents from Hydnophytum formicarum Jack.
}

\author{
Supaluk Prachayasittikul ${ }^{1, *}$, Prasit Buraparuangsang ${ }^{1}$, Apilak Worachartcheewan ${ }^{2}$, \\ Chartchalerm Isarankura-Na-Ayudhya ${ }^{2}$, Somsak Ruchirawat ${ }^{3}$ and \\ Virapong Prachayasittikul ${ }^{2, *}$
}

${ }^{1}$ Department of Chemistry, Faculty of Science, Srinakharinwirot University, Sukhumvit 23, Bangkok 10110, Thailand

${ }^{2}$ Department of Clinical Microbiology, Faculty of Medical Technology, Mahidol University, Bangkok 10700, Thailand

${ }^{3}$ Laboratory of Medicinal Chemistry, Chulabhorn Research Institute, Vipavadee Rangsit Highway, Bangkok 10210, Thailand

* Authors to whom correspondence should be addressed; S. Prachayasittikul: E-mail: supaluk@swu.ac.th; Tel.662-664-1000 ext. 8209, Fax 662-259-2097; V. Prachayasittikul: E-mail: mtvpr@mahidol.ac.th; Tel.662-418-0227, Fax 662-412-4110

Received: 1 April 2008; in revised form: 17 April 2008 / Accepted: 17 April 2008 / Published: 18 April 2008

\begin{abstract}
Hydnophytum formicarum Jack. (Rubiaceae) is a medicinal plant whose tubers possesses cardiovascular, anti-inflammatory and antiparasitic effects and have been used for the treatment of hepatitis, rheumatism and diarrhea. Herein we report the isolation of its active constituents and the testing of their antimicrobial activity against 27 strains of microorganisms using an agar dilution method and of their antioxidative activity using the DPPH and SOD assays. The results show that the crude hexane, dichloromethane, ethyl acetate and methanol extracts exert such activities. Particularly, the crude ethyl acetate extract exhibits antigrowth activity against many Gram-positive and Gram-negative bacteria with MIC $256 \mu \mathrm{g} / \mathrm{mL}$. Shewanella putrefaciens ATCC 8671 is completely inhibited at a lower MIC $(128 \mu \mathrm{g} / \mathrm{mL})$. Interestingly, Corynebacterium diphtheriae NCTC 10356 is inhibited by all the tested extracts. Significantly, the ethyl acetate extract is also the most potent antioxidant, showing $83.31 \%$ radical scavenging activity with $\mathrm{IC}_{50} 8.40$ $\mu \mathrm{g} / \mathrm{mL}$ in the DPPH assay. The other extracts display weak to moderate antioxidative
\end{abstract}


activities, ranging from $28.60-56.80 \%$ radical scavenging. The SOD assay shows that methanol extract exhibits the highest activity (74.19\% inhibition of superoxide radical). The dichloromethane and ethyl acetate extracts display comparable SOD activity. The promising bioactivities of the crude ethyl acetate extract guided the first isolation of bioactive flavonoid and phenolic compounds: isoliquiritigenin (2), protocatechualdehyde (3), butin (4) and butein (5) from this species. Their structures have been fully established by $1 \mathrm{D}$ and 2D NMR. In addition, stigmasterol was isolated from the crude hexane and dichloromethane extracts. The antimicrobial and cytotoxic activities of compounds 3-5 were evaluated. The tested compounds were inactive against HuCCA-1 and KB cell lines, showing $\mathrm{ED}_{50}>10 \mu \mathrm{g} / \mathrm{mL}$. Protocatechualdehyde (3) completely inhibits the growth of Plesiomonas shigelloides with MIC $\leq 60 \mu \mathrm{g} / \mathrm{mL}$. As a result, we propose that Hydnophytum formicarum Jack. can serve as a new source enriched with potent antioxidative and antimicrobial agents.

Keywords: Hydnophytum formicarum Jack., antimicrobial, antioxidative and cytotoxic activities.

\section{Introduction}

Hydnophytum formicarum Jack. or ant plant, a medicinal plant of the Rubiaceae family [1, 2], is known in Thai as Hua roi roo [3] as well as by other local names. It is commonly found in the East and South of Thailand, South-East Asia, Papua New Guinea and Pacific Islands [2]. Its tuber possesses cardiovascular, antiinflammatory and antiparasitic effects, and is used for the relief of skin rashes and as a neurotonic [4], and as a treatment of headache [5], hepatitis, rheumatism and diarrhea [6, 7].

Hydnophytum formicarum Jack. has several branches with opposite fleshy, oval leaves and small sessile, axillary white flowers and red berries [1]. The typical size varies from 10-12 cm to 30-50 cm [8]. The tubers' cavities have one or more entrance holes communicating with the outside, through which it absorbs both water and substances to obtain essential nutrients from faecal material and debris brought in by ants. In return the plants provide food for the ants in a form of nectar or other proteinrich sources and for this reason Hydnophytum formicarum Jack. is well known as the ant plant.

The plant has a long tradition of use in Thai traditional medicine as a mixture with other plant extracts for the treatment of diabetes. However, no chemical isolation and characterization of the components of this medicinal plant have been reported. The xanthine oxidase inhibitory activity of the Hydnophytum formicarum Jack. was previously reported [6]. Additionally, its antiproliferative activity against human HT-1080 fibrosarcoma cells was described [7]. The many interesting reports concerning the medicinal value of Hydnophytum formicarum Jack. as a folk remedy and its diverse reported biological activitives prompted us to investigate the bioactive ingredients of the tubers of Hydnophytum formicarum Jack to search for new sources of medicinal agents. Herein, we report the isolation, structure elucidation and biological evaluation of the antimicrobial and antioxidative activities, including cytotoxic effects, of the identifed components.

\section{Results and Discussion}




\section{Isolation and structure elucidation}

The crude hexane extract of dried Hydnophytum formicarum Jack. tubers was repeatedly chromatographed on a silica gel column using gradient elution with hexane-acetone mixtures to give a green gum containing a white solid. Recrystallization provided stigmasterol (1) of m.p. $152-153^{\circ} \mathrm{C}$ [9]. The structure was confirmed by comparison of its ${ }^{1} \mathrm{H}$ - and ${ }^{13} \mathrm{C}-\mathrm{NMR}$ spectral data with that of an authentic sample. Similarly, the crude dichloromethane extract was isolated and purified as described to give the stigmasterol (1). The crude ethyl acetate extract was separated by repeated silica gel column and preparative TLC using gradient elution to obtain four compounds: isoliquiritigenin (2), protocatechualdehyde (3), butin (4) and butein (5) (Figure 1), all of which have been isolated from Hydnophytum formicarum Jack. for the first time. The structures of 2-5 were elucidated using UV, IR, and comparison of their ${ }^{1} \mathrm{H}$ - and ${ }^{13} \mathrm{C}-\mathrm{NMR}$ with the literature data [10-18]. In this study, 2D NMR spectral data was also obtained.

Figure 1. Structures of compounds $1-5$.

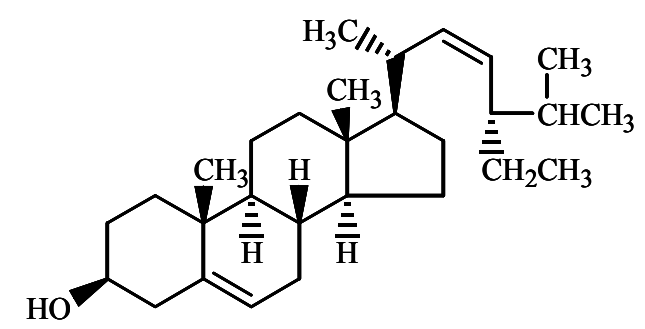

1<smiles>O=C1CC(c2ccc(O)c(O)c2)Oc2cc(O)ccc21</smiles>

4<smiles>O=C(/C=C/c1ccc(O)cc1)c1ccc(O)cc1O</smiles>

2<smiles>O=Cc1ccc(O)c(O)c1</smiles>

3<smiles>O=C(/C=C/c1ccc(O)c(O)c1)c1ccc(O)cc1O</smiles>

5

\section{Biological activities}

\section{Antimicrobial activity}

The crude hexane, dichloromethane, ethyl acetate and methanol extracts, and the isolates 3-5 from Hydnophytum formicarum Jack. were tested for antimicrobial activity against 27 strains of microorganisms using the agar dilution method [19]. The results (Table 1) show that all the tested extracts completely inhibit the growth of the Gram-positive bacterium C. diphtheriae NCTC 10356 with MIC $256 \mu \mathrm{g} / \mathrm{mL}$. This strain was the most sensitive, as it was the only one inhibited by the crude hexane and dichloromethane extracts. Other microorganisms: A. xylosoxidan ATCC 2706, S. aureus 
ATCC 25923, M. lutens ATCC 10240, S. dysenteriae, S. pyogenes II, A. hydrophila and B. cereus were completely inhibited by the crude ethyl acetate extract, with MIC $256 \mu \mathrm{g} / \mathrm{mL}$. The ethyl acetate extract completely inhibits the growth of $S$. putrefaciens ATCC 8671 with a low MIC $(128 \mu \mathrm{g} / \mathrm{mL})$. In addition, the crude methanol extract displays antigrowth activity against $S$. pyogenes II and B. cereus, with MICs of $256 \mu \mathrm{g} / \mathrm{mL}$.

The antimicrobial activity of pure compounds $3-5$ isolated from the crude ethyl acetate extract was similarly evaluated. It was found (Table 1) that only compound $\mathbf{3}$ displayed complete inhibiton against $P$. shigelloides, with MIC $\leq 60 \mu \mathrm{g} / \mathrm{mL}$. In comparison ampicillin, a positive control, showed antigrowth activity against $P$. shigelloides at MIC $10 \mu \mathrm{g} / \mathrm{mL}$.

Table 1. Antimicrobial activity of Hydnophytum formicarum Jack.

\begin{tabular}{|c|c|c|c|}
\hline Compound $^{\mathrm{a}, \mathrm{b}}$ & Microorganism & Gram & $\begin{array}{l}\text { MIC }^{\mathrm{c}} \\
(\mu \mathrm{g} / \mathrm{mL})\end{array}$ \\
\hline Crude hexane extract & C. diphtheriae NCTC 10356 & + & 256 \\
\hline Crude dichloromethane extract & C. diphtheriae NCTC 10356 & + & 256 \\
\hline Crude ethyl acetate extract & $\begin{array}{l}\text { C. diphtheriae NCTC } 10356 \\
\text { A. xylosoxidan ATCC } 2706 \\
\text { S. aureus ATCC } 25923 \\
\text { M. lutens ATCC } 10240 \\
\text { S. dysenteriae } \\
\text { S. pyogenes II } \\
\text { A. hydrophila } \\
\text { B. cereus } \\
\text { S. putrefaciens ATCC } 8671 \\
\end{array}$ & $\begin{array}{l}+ \\
- \\
+ \\
+ \\
- \\
+ \\
- \\
+ \\
- \\
\end{array}$ & $\begin{array}{l}256 \\
256 \\
256 \\
256 \\
256 \\
256 \\
256 \\
256 \\
128 \\
\end{array}$ \\
\hline Crude methanol extract & $\begin{array}{l}\text { C. diphtheriae NCTC } 10356 \\
\text { S. pyogenes II } \\
\text { B. cereus }\end{array}$ & $\begin{array}{l}+ \\
+ \\
+\end{array}$ & $\begin{array}{l}256 \\
256 \\
256 \\
\end{array}$ \\
\hline Compound 3 & P. shigelloides & - & $\leq 60$ \\
\hline Ampicillin & P. shigelloides & - & 10 \\
\hline
\end{tabular}

a: compound 4 was tested at $64 \mu \mathrm{g} / \mathrm{mL}$, no growth inhibition.

b: compound 5 was tested at $115 \mu \mathrm{g} / \mathrm{mL}$, no growth inhibition.

c: minimum inhibitory concentration

\section{Antioxidant activity}

The antioxidant activity of the crude extracts was tested using the DPPH (2,2-diphenyl-1picrylhydrazyl) [20] and SOD (superoxide dismutase) [21] assays. The results (Table 2) demonstrate that all the tested crude extracts possess some antioxidative activity. In the DPPH assay, the crude ethyl acetate extract at $333.33 \mu \mathrm{g} / \mathrm{mL}$ exhibits highest radical scavenging activity $(83.31 \%)$ with $\mathrm{IC}_{50}$ of $8.40 \mu \mathrm{g} / \mathrm{mL}$, while $\alpha$-tocopherol, a positive control, shows antioxidative activity with $\mathrm{IC}_{50} 6.67$ $\mu \mathrm{g} / \mathrm{mL}$ (Figure 2). The crude dichloromethane and methanol extracts showed moderate activity (55.70 
and $56.80 \%$ radical scavanging, respectively). The nonpolar crude hexane extract is a weak antioxidant, showing $28.60 \%$ radical scavenging activity.

The SOD activity at $300 \mu \mathrm{g} / \mathrm{mL}$ shows that the crude methanol extract exhibits the highest $(74.19$ \%) inhibition of superoxide anion. The native SOD, a positive control (7.6 U) exhibits $75.98 \%$ inhibition. The crude dichloromethane and ethyl acetate extracts exert moderate SOD activity (62.24 and $67.91 \%$ inhibition, respectively) as shown in Figure 3. The hexane extract exhibits weak SOD activity.

Table 2. Antioxidative activity of Hydnophytum formicarum Jack.

\begin{tabular}{|l|c|c|}
\hline Compound & $\begin{array}{c}\text { Radical scavenging activitya (\%) } \\
(\mathbf{3 3 3 . 3 3} \mathbf{\mu g} / \mathbf{m L})\end{array}$ & $\begin{array}{c}\text { Superoxide dismutase activityb (\%) } \\
\mathbf{( 3 0 0} \mathbf{~} \mathbf{g} / \mathbf{m L})\end{array}$ \\
\hline Crude hexane extract & 28.60 & 25.86 \\
\hline Crude dichloromethane extract & 55.70 & 62.24 \\
\hline Crude ethyl acetate extract & 83.31 & 67.91 \\
\hline Crude methanol extract & 56.80 & 74.19 \\
\hline
\end{tabular}

a: $\alpha$-Tocopherol was used as a positive control.

b: Native SOD (7.6 U) from bovine erythrocytes was used as a positive control.

Figure 2. Radical scavenging activity of $\alpha$-tocopherol and ethyl acetate extract.

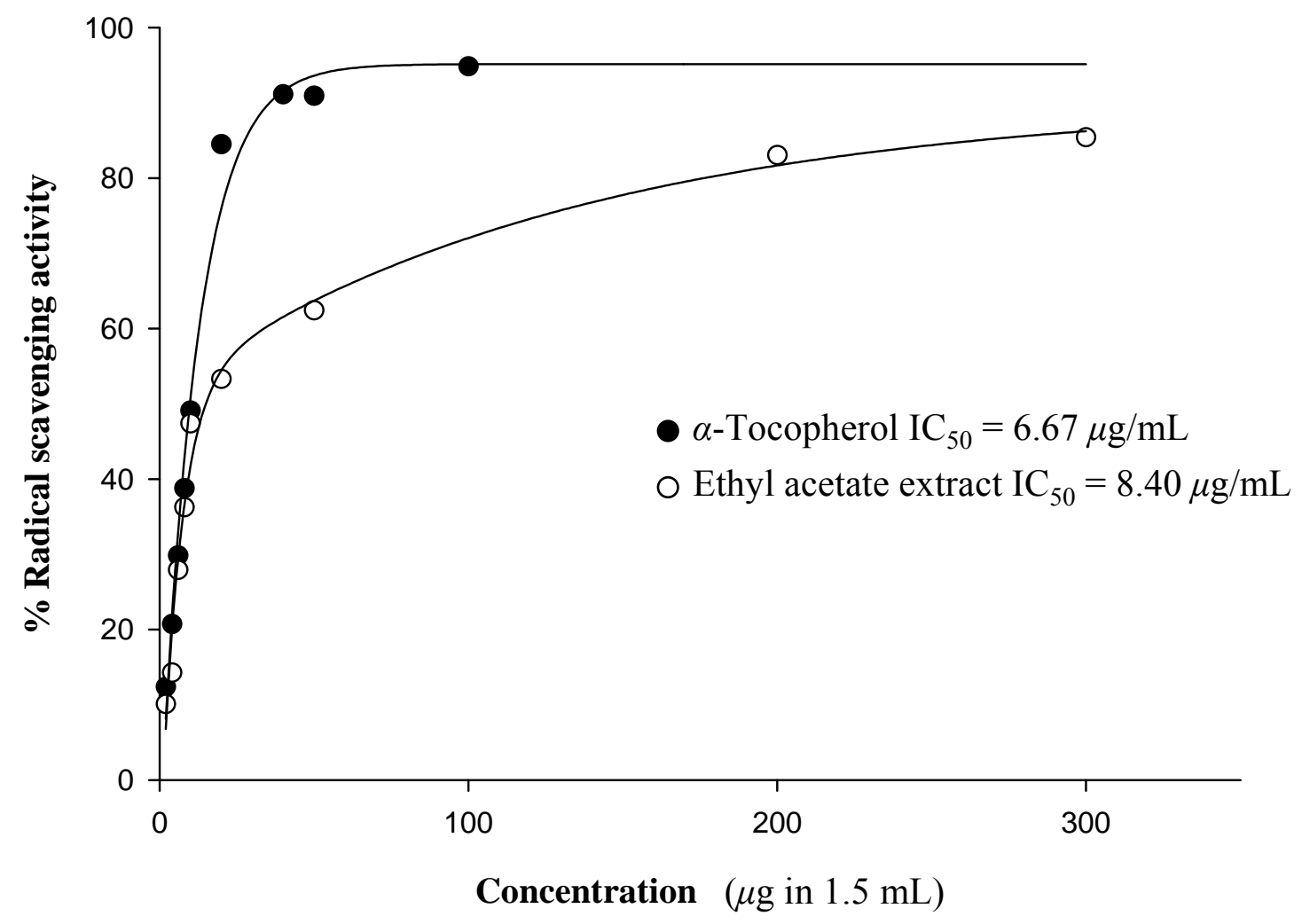


Figure 3. Superoxide dismutase activity of crude extracts.

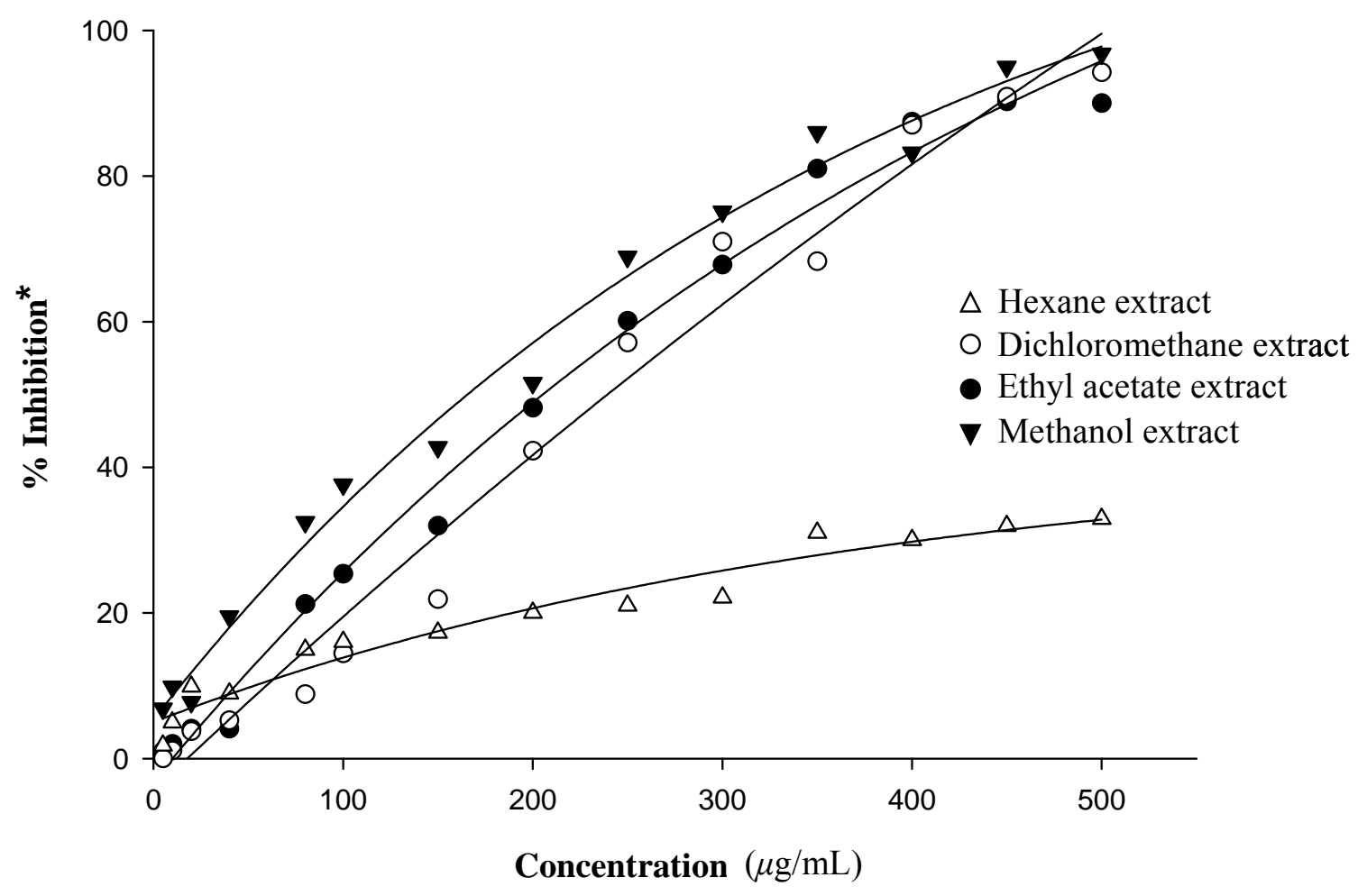

*Note: Native SOD $(7.6 \mathrm{U})=75.98 \%$ inhibition

\section{Cytotoxic activity}

The isolates 3, 4 and 5 were evaluated for cytotoxic activity [22] against two cell lines: HuCCA-1 and $\mathrm{KB}$, using etoposide as a positive control. It was observed that the tested compounds $\mathbf{3}-\mathbf{5}$ (Table 3) were all inactive, showing $\mathrm{ED}_{50}>10 \mu \mathrm{g} / \mathrm{mL}$.

Table 3. Cytotoxic activities of compounds $3-5$.

\begin{tabular}{|l|c|c|}
\hline \multirow{2}{*}{ Compound } & \multicolumn{2}{|c|}{ ED $_{50}(\mu \mathrm{g} / \mathrm{mL})^{*}$} \\
\cline { 2 - 3 } & HuCCA-1 cell line & KB cell line \\
\hline $\mathbf{3}$ & $>10$ & $>10$ \\
$\mathbf{4}$ & $>11$ & $>11$ \\
$\mathbf{5}$ & $>11$ & $>11$ \\
Etoposide & 4.0 & 0.25 \\
\hline
\end{tabular}

* $\mathrm{ED}_{50}$ ">" indicates that compounds are inactive at that concentration or inhibit cell growth less than $50 \%$.

The antimicrobial and antioxidative assay results (Tables 1 and 2) have shown that all the tested extracts exert such some biological activity. Particularly, the crude ethyl acetate extract exhibited antigrowth activity against many Gram-positive and Gram-negative bacteria with MIC $256 \mu \mathrm{g} / \mathrm{mL}$, 
while S. putrefaciens ATCC 8671 is completely inhibited at a lower MIC of $128 \mu \mathrm{g} / \mathrm{mL}$. It is interesting to note that all the tested extracts can inhibit the growth of $C$. diphtheriae NCTC 10356. However, antigrowth activity against the yeasts tested, S. cereviseae ATCC 2601 and C. albicans ATCC 90028, was not observed.

The antioxidative activity (DPPH assay) of the tested extracts indicated moderate to high (55.70$83.31 \%)$ radical scavenging activities, except for the hexane extract, is a weak antioxidant $(28.60 \%$ radical scavenging). Significantly, the ethyl acetate extract is the most potent in this respect, exhibiting $83.31 \%$ radical scavenging activity with $\mathrm{IC}_{50} 8.40 \mu \mathrm{g} / \mathrm{mL}$. In the SOD assay the methanol extract exerted the highest inhibition (74.19\%) of superoxide radical. It is interesting to note that the activity increases with higher polar solvent extracts. It was reported that methanol and methanol-water extracts of Hydnophytum formicarum Jack. showed xanthine oxidase inhibitory (XO) activity (10.3 and 32.5\%, respectively) at $50 \mu \mathrm{g} / \mathrm{mL}$, while its water extract at $100 \mu \mathrm{g} / \mathrm{mL}$ exhibited $<0.1 \%$ XO activity [6]. In addition, methanol and methanol- $\mathrm{H}_{2} \mathrm{O}$ (1:1) extracts of Hydnophytum formicarum Jack. displayed potent antiproliferative activity against human lung A549 adenocarcinoma cell, with an $\mathrm{ED}_{50}$ value of less than $4 \mu \mathrm{g} / \mathrm{mL}$. Such activity was observed against other cell lines, such as highly metastatic human HT-1080 fibrosarcoma, human cervical HeLa and murine colon 26-L5 carcinoma cells [7]. Our findings have led to the first isolation of flavonoid and phenolic pure compounds 2-5 from the ethyl acetate extract of Hydnophytum formicarum Jack. so it is conceivable that the potent antioxidative activity (DPPH assay) of the ethyl acetate extract may result from these constituents 2-5. Their structures have been fully established by 1D and 2D NMR. Additionally, stigmasterol was also isolated from the crude hexane and dichloromethane extracts.

The isolated compounds 3-5 were tested for antimicrobial and cytotoxic activities. The tested compounds were inactive against HuCCA-1 and $\mathrm{KB}$ cell lines, $\mathrm{ED}_{50}>10 \mu \mathrm{g} / \mathrm{mL}$. Only protocatechualdehyde (3) exhibits antigrowth activity against $P$. shigelloides, with MIC $\leq 60 \mu \mathrm{g} / \mathrm{mL}$. Due to the limited quantity available of the isolated compounds, compounds $\mathbf{4}$ and $\mathbf{5}$ were tested at 64 and $115 \mu \mathrm{g} / \mathrm{mL}$, respectively. No antimicrobial activity was observed at these concentrations.

Isoliquiritigenin (2) was first found in nature in 1953 from Dahlia variabilis (Compositae) [23]. It was also isolated from Glycyrrhiza glabra (licorice) [24], Sinofranchetia chinensis [25] and recently from Broussonetia papyrifera (paper mullery) [26]. Additionally, isoliquiritigenin glycoside was isolated from woody parts of the thickening root of Glycyrrhiza glabra [27].

Diverse biological activities of isoliquiritigenin were reported. For example, it exhibited effects on cardiac [28] and aortic smooth muscle [29], and showed anti-platelet [30], vasorelaxant [31], antioxidant [32] and antitumor activities [33]. Particularly, isoliquiritigenin was very potent antioxidant toward LDL oxidation [24], as well as, xanthine oxidase inhibitor [25] and tyrosinase inhibitor [26]. It was first reported to inhibit proliferation and induce apoptosis of human hepatoma (Hep G2 cells) via p53-dependent pathway [34]. Inhibition of tumor necrosis factor- $\alpha$ (TNF- $\alpha$ ) on the induction of ROS production and neutrophil adhesion to endothelial cell was also described [35]. Moreover, its biological activities including the decrease of prostaglandin E2 and nitric oxide production in RAW 264.7 mouse macrophages cell [36], potent antitumor activity and inhibition of prostate cancer cell [37] were documented.

Our studies show that protocatechualdehyde (3) exhibits complete antigrowth activity against $P$. shigelloides, with MIC $\leq 60 \mu \mathrm{g} / \mathrm{mL}$. Recently, the phenolic compound 3 has been reported to 
significantly inhibit the growth of Oenococcus oeni VF [38]. Such compound was isolated from fruit of Amomun tsao-ko [39], root of Salvia miltiorrhiza [40], Salvia officinalis [41] and fruit of Ganoderma applanatum [42]. It exerted diverse biological activities e.g. antiproliferative, antioxidant, antitumor [43], reduced blood glucose level and inhibited lens opacity in streptozotocin induced diabetic cataract in rats [44] and inhibited HIV-1 replication in acute cytolytic infection of CEM cells [45].

The specific rotation of butin (4) was $-87^{\circ}$ and was first found in Hydnophytum formicarum Jack. Previously, butin was isolated from the seeds of Butea frondosa and was shown to possess postcoital antiimplantation and anticonceptive activities in the pregnant rats when administered orally during the implantation period [46]. Furthermore, butin was found in Vernonia anthelmintica Willd and in dried vine stem of Spatholobus suberectus Dunn [47], which showing the greatest (80.1\%) anti-tyrosinase activity of human melanocytes.

Butein was isolated from Butea frondosa [48], Viguiera multiflora (Nutt.) [49], Baeria chrysostoma (F. and M.) [49], Cosmos sulphureus [50], Dahlia variabilis [49], Coreopsis maritima [51], Coreopsis gigantea [51], heartwood of Dalbergia odorifera T. [52] and from Rhus verniciflua Stokes [53]. This report constitutes the first isolation of butein (5) from Hydnophytum formicarum Jack. It was reported that butein served as a powerful antioxidant against lipid and LDL peroxidation by its free radical scavenging action and metal ion chelation [52, 54-56]. Moreover, butein exhibited other bioactivities such as anti-inflammatory [53, 57-58], strong aromatase inhibitor with $\mathrm{IC}_{50}$ less than $5 \mu \mathrm{M}(3.75 \mu \mathrm{M})$ [59], inhibited TNF- $\alpha$ [58], inhibited cyclooxygenase 2 by lipopolysaccharide, inhibited nitric oxide production and inducible nitric oxide synthase (iNOS) [57], inhibited cAMPspecific phosphodiesterase [60] and angiotensin converting enzyme [61] as well as antinephritic effects [62], induced apoptosis in HL-60 cells [63] and B16 melanoma cells [64].

It is well known that stigmasterol is a phytosterol isolated from soy beans and other plants. Stigmasterol showed antioxidative activity, determined by the thiocyanate method [65], and lipid antioxidant properties [66]. In addition, stigmasterol significantly suppressed HMG-CoA reductase activity leading to approximately $11 \%$ reduction in plasma cholesterol levels in Wistar and WKY rats feeding $0.5 \%$ stigmasterol [67].

According to the reported biological activities of isoliquiritigenin (2), protocatechualdehyde (3), butin (4), butein (5) and stigmasterol (1) our results provide remarkable support for the use of Hydnophytum formicarum Jack. as traditional medicine, e.g. for treatment of diabetes, rheumatism and diarrhea. Furthermore, Hydnophytum formicarum Jack. can be considered as a new natural source of the bioactive flavonoid and phenolic compounds 2-5.

\section{Conclusions}

In conclusion, we have provided the experimental data to support the use of Hydnophytum formicarum Jack. as a herbal medicine. Significantly, the crude ethyl acetate extract exhibited potent antioxidative activity (DPPH assay), with $\mathrm{IC}_{50} 8.40 \mu \mathrm{g} / \mathrm{mL}$, as well as antimicrobial activity. In addition, the other tested crude hexane, dichloromethane and methanol extracts show antimicrobial and antioxidative activities. The compounds 2-5 isolated from the ethyl acetate extract are effective antioxidants and antimicrobials. Although these compounds 2-5 were previously isolated from other 
plants, they have been first found in Hydnophytum formicarum Jack. by our group. Their structures have been fully established by 1D and 2D NMR. The compounds 3-5 were tested for antimicrobial and cytotoxic activities. The tested compounds were inactive against HuCCA-1 and KB cell lines, showing $\mathrm{ED}_{50}>10 \mu \mathrm{g} / \mathrm{mL}$. Protocatechualdehyde (3) completely inhibits the growth of $P$. shigelloides, with MIC $\leq 60 \mu \mathrm{g} / \mathrm{mL}$. As a result, the Hydnophytum formicarum Jack. could serve as a new natural source enriched with potent antioxidative and antimicrobial agents. Our isolates 2-5 are potential lead compounds to be further structurally modified leading to new and effective therapeutics. Other biological activities of Hydnophytum formicarum Jack. are being investigated.

\section{Experimental}

\section{General}

Melting points were determined on an Electrothermal melting point apparatus (Electrothermal 9100) and are reported without correction. ${ }^{1} \mathrm{H}$ - and ${ }^{13} \mathrm{C}-\mathrm{NMR}$ spectra were recorded on a Bruker AM 400 instrument with a 400/100 MHz operating frequency using deuterochloroform or deuteromethanol solutions with tetramethylsilane as internal standard. Mass spectra were determined using a Finnigan MAT INCOS 50 mass spectrometer. Infrared spectra (IR) were obtained on Perkin Elmer System 2000 FTIR. Ultraviolet (UV) spectra were measured with Milton Roy Spectronic 3000 Array. Optical rotation was measured in methanol solution with sodium D line $(590 \mathrm{~nm})$ on JASCO DIP370 digital polarimeter. Column chromatography was carried out using silica gel $60(0.063-0.200 \mathrm{~mm})$ and silica gel 60 (particle size less than $0.063 \mathrm{~mm}$ ). Thin Layer Chromatography (TLC) and preparative Thin Layer Chromatography were carried out on silica gel $60 \mathrm{PF}_{254}$ (cat. No. 7747 E., Merck).

\section{Plant material}

Tubers of Hydnophytum formicarum Jack. were purchased from the "Chao krom pur" traditional drug store, Bangkok. It has been identified (BKF 135252) by The Forest Herbarium, Royal Forestry Department, Bangkok. A voucher specimen has been deposited at Department of Chemistry, Faculty of Science, Srinakharinwirot University, Bangkok, Thailand.

\section{Cell cultures}

HuCCA-1 cells were established from chlolangiocarcinomas experimentally induced in hamsters. The cell lines were characterized and have been maintained in CRI laboratory ever since 1994 in Ham's F12 culture medium (GIBCO Laboratories, Grand Island NY) supplemented with 10\% fetal bovine serum (FBS, Hyclone Laboratories, Logan, UT), $100 \mathrm{U} / \mathrm{mL}$ penicillin and $100 \mu \mathrm{g} / \mathrm{mL}$ streptomycin. The KB cell lines, originally derived from epidermoid carcinoma of the floor of the oral cavity and commonly used as a reference laboratory standard for cytotoxicity assay, has been maintained in CRI laboratory in DMEM (Dulbecco's modified Eagle medium). 
Extraction and Isolation

\section{Extraction}

The air-dried tubers of Hydnophytum formicarum Jack. (4 kg) were ground and extracted with hexane $(10 \mathrm{~L} \times 7$ days $\times 3)$, followed by filtration. The filtrates were combined and evaporated to dryness under reduced pressure to obtain crude hexane extract. Similary, the extraction was carried out using dichloromethane, ethyl acetate and methanol to give the corresponding dichloromethane, ethyl acetate and methanol extracts.

\section{Isolation}

The crude hexane extract ( $15 \mathrm{~g}$ ) was purified by column chromatography on silica gel. Elution was conducted initially with hexane gradually enriched with acetone. All fractions were collected, monitored by TLC and combined as appropriate. The solvents were evaporated to dryness in vacuo to afford 14 fractions (H1 - H14). Fractions H9 and H10, eluted by 3-5\% acetone-hexane, were combined and evaporated to give green gum containing white crystals $(2.7 \mathrm{~g})$. This mixture was further separated by column chromatography over silica gel using gradient elution (hexane-acetone) to give a white solid. Recrystallization of the solid from hexane-ethyl acetate gave stigmasterol (1, 496 mg), m.p. $152-153^{\circ} \mathrm{C}$.

The crude dichloromethane extract (20 g) was subjected to silica gel column. Initial elution with hexane then gradually increasing with acetone and finally enriched with methanol gave fractions which were collected and combined according to TLC chromatogram. The solvents were evaporated to dryness to afford 18 fractions (C1 - C18). Fractions C9 and C10 (2.31 g) was repeatedly isolated by silica gel column. Elution with increasing polarity (hexane-acetone) afforded white amorphous compound which was recrystallized from hexane-ethyl acetate to give stigmasterol (1, $77 \mathrm{mg})$, m.p. $152-153^{\circ} \mathrm{C}$.

The crude ethyl acetate extract (59 g obtained from $10 \mathrm{~kg}$ of Hydnophytum formicarum Jack. which was extracted as described) was isolated by silica gel column. Elution with hexane, then gradually increasing polarity with acetone and finally enriched with methanol were performed. All fractions were collected and combined as usual using TLC monitoring. The solvents were evaporated to dryness to give 11 fractions (E1 - E11). Three selected main fractions (E1 - E3) were isolated and purified.

Fraction E1 (13.51 g, yellowish green) was obtained by elution with 20\% acetone-hexane. The mixture was subjected to silica gel column eluting with $2 \%$ methanol-dichloromethane, and then further purified by preparative TLC using 5\% methanol-dichloromethane as a mobile phase to afford a yellow solid. Recrystallization from dichloromethane-methanol furnished 1-(2,4-dihydroxyphenyl)-3(4-hydroxyphenyl)-2-propen-1-one (2',4,4'-trihydroxychalcone, isoliquiritigenin, 2, $15 \mathrm{mg}$ ); yellow solid; m.p. $182-183^{\circ} \mathrm{C}$; (lit. $202^{\circ} \mathrm{C}$ [10], 193.5-195 ${ }^{\circ} \mathrm{C}$ [11]); UV $\lambda_{\max }(\mathrm{MeOH}) \mathrm{nm}(\log \varepsilon): 369$ (7.42) (in methanol [13] $258 \mathrm{sh}, 298 \mathrm{sh}, 367)$; FTIR $v_{\max }\left(\mathrm{KBr}, \mathrm{cm}^{-1}\right): 3514,3288,1634,1589,1514,1371$, 1229, 1175 (lit. [11]: 3380, 1626, 1607, 1585, 1543, 1370, 1343, 1320, 1287); ${ }^{1} \mathrm{H}-\mathrm{NMR}\left(\mathrm{CD}_{3} \mathrm{OD}\right): \delta$ $7.75(1 \mathrm{H}, d, J=15.4 \mathrm{~Hz}, \mathrm{H}-\beta), 7.74\left(1 \mathrm{H}, d, J=8.8 \mathrm{~Hz}, \mathrm{H}-6^{\prime}\right), 7.47(2 \mathrm{H}, d, J=8.6 \mathrm{~Hz}, \mathrm{H}-2,6), 7.36$ $(1 \mathrm{H}, d, J=15.4 \mathrm{~Hz}, \mathrm{H}-\alpha), 6.80(2 \mathrm{H}, d, J=8.6 \mathrm{~Hz}, \mathrm{H}-3,5), 6.36\left(1 \mathrm{H}, d d, J=8.8,2.4 \mathrm{~Hz}, \mathrm{H}-5^{\prime}\right), 6.31$ 
$\left(1 \mathrm{H}, d, J=2.4 \mathrm{~Hz}, \mathrm{H}-3^{\prime}\right) ;{ }^{13} \mathrm{C}-\mathrm{NMR}\left(\mathrm{CD}_{3} \mathrm{OD}\right): \delta 191.92(\mathrm{CO}), 165.71\left(\mathrm{C}-4^{\prime}\right), 164.36\left(\mathrm{C}-2^{\prime}\right), 159.50$ (C-4), $144.40(\mathrm{CH}-\beta), 131.72\left(\mathrm{CH}-6^{\prime}\right), 130.48(\mathrm{CH}-2,6), 126.58(\mathrm{C}-1), 117.20(\mathrm{CH}-\alpha), 115.90(\mathrm{CH}-$ 3,5), $\left.113.61(\mathrm{C}-1 ')^{\prime}\right), 108.18\left(\mathrm{CH}-5^{\prime}\right), 103.08\left(\mathrm{CH}-3^{\prime}\right)$; EIMS $m / z$ (\% relative intensity):256 $\left(\mathrm{M}^{+}, 65\right)$, 255 (60), 239 (15), 163 (15), 150 (27), 137 (29), 28 (100) (lit. [12]: 256 (M+, 100), 255 (55), 239 (14), 192 (26), 163 (37), 150 (20), 137 (90), 120 (50)).

Fraction E2 (6.75 g) obtained from elution with 30\% acetone-hexane, was further purified by silica gel column chromatography. Elution with increasing amounts of methanol in dichloromethane, then purification by preparative TLC using 3\% methanol-dichloromethane as a developing solvent afforded a semi-solid. Recrystallization from methanol-ethyl acetate gave 3,4-dihydroxy-benzaldehyde (protocatechualdehyde, 3, $15 \mathrm{mg}$ ). Brown crystals, m.p. $153-154{ }^{\circ} \mathrm{C}$ (lit. $154{ }^{\circ} \mathrm{C}$ [10], 155-156 ${ }^{\circ} \mathrm{C}$ [14], 151-153 $\left.{ }^{\circ} \mathrm{C}[15]\right) ; ~ U V ~ \lambda_{\max }(\mathrm{MeOH}) \mathrm{nm}(\log \varepsilon): 232$ (6.81), 278 (6.89), 312 (6.94) (in ethanol [16]: 209 (4.17), 234 (4.15), 281 (4.01), 315 (3.97), 360 (3.05)); FTIR $v_{\max }\left(\mathrm{KBr}, \mathrm{cm}^{-1}\right)$ : 3326, 2875, 2825, 1647, 1595, 1537, 1443, 1168, 1119 (lit. [14]: 3220, 1650, 1595, 1440, 1375, 1296, 1165; [15]: 3240, 1680, 1600); ${ }^{1} \mathrm{H}-\mathrm{NMR}\left(\mathrm{CD}_{3} \mathrm{OD}\right): \delta 9.63(1 \mathrm{H}, \mathrm{s}, \mathrm{CHO}), 7.25(1 \mathrm{H}, b r s, \mathrm{H}-2), 7.23(1 \mathrm{H}, b r d, \mathrm{H}-6), 6.87(1 \mathrm{H}$, $d, J=8.0 \mathrm{~Hz}, \mathrm{H}-5) ;{ }^{13} \mathrm{C}-\mathrm{NMR}\left(\mathrm{CD}_{3} \mathrm{OD}\right): \delta 191.93$ (CHO), 151.74 (C-4), 145.18 (C-3), 129.29 (C-1),

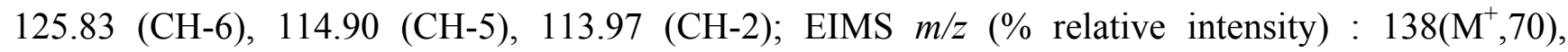
137(100), 109(18).

Fraction E3 (2.26 g of brown solid obtained from 40\% acetone-hexane elution) was rechromatographed on a silica gel column. Elution with $6 \%$ methanol-dichloromethane afforded a brown gum, which was further purified by preparative TLC on silica gel developing five times with $6 \%$ methanol-dichloromethane to provide two bands. The lower band $\left(\mathrm{R}_{f}=0.40\right)$ was recrystallized from acetone-methanol to give 2-(3,4-dihydroxyphenyl)-2,3-dihydro-7-hydroxy-4H-1-benzopyran-4one $\left(3,4^{\prime}, 7\right.$-trihydroxyflavanone, butin, $\left.4,27.9 \mathrm{mg}\right)$. The higher band $\left(\mathrm{R}_{f}=0.44\right)$ was recrystallized from dichloromethane to yield 1-(2,4-dihydroxyphenyl)-3-(3,4-dihydroxyphenyl)-2-propen-1-one (2',3,4,4'-tetrahydroxychalcone, butein, 5, $18.7 \mathrm{mg})$.

Butin (4). Yellow solid, m.p. $204-205^{\circ} \mathrm{C}$ (lit. $205^{\circ} \mathrm{C}$ [10], 224-225 ${ }^{\circ} \mathrm{C}$ [17]); UV $\lambda_{\max }(\mathrm{MeOH}) \mathrm{nm}(\log$ ع): 233 (6.76), 278 (6.84), 311 (6.89) (lit. [17] 225 (4.21), 327 (3.99) in methanol); FTIR $v_{\max }(\mathrm{KBr}$,

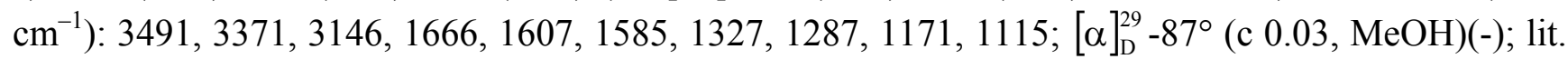
[17], $-18.7^{\circ} \pm 0.8^{\circ}$; c 0.5, MeOH [18]); ${ }^{1} \mathrm{H}-\mathrm{NMR}\left(\mathrm{CD}_{3} \mathrm{OD}\right): \delta 7.69(1 \mathrm{H}, \mathrm{d}, J=8.7 \mathrm{~Hz}, \mathrm{H}-5), 6.87(1 \mathrm{H}$, $\left.d, J=1.8 \mathrm{~Hz}, \mathrm{H}-2^{\prime}\right), 6.77\left(1 \mathrm{H}, d, J=8.2 \mathrm{~Hz}, \mathrm{H}-5^{\prime}\right), 6.74\left(1 \mathrm{H}, d d, J=8.2,1.8 \mathrm{~Hz}, \mathrm{H}-6^{\prime}\right), 6.44(1 \mathrm{H}, d d, J$ $=8.7,2.2 \mathrm{~Hz}, \mathrm{H}-6), 6.32(1 \mathrm{H}, d, J=2.2 \mathrm{~Hz}, \mathrm{H}-8), 5.22(1 \mathrm{H}, d d, J=13.2,2.8 \mathrm{~Hz}, \mathrm{H}-2), 2.94(1 \mathrm{H}, d d, J$ $=13.2,17.0 \mathrm{~Hz}, \mathrm{H}-3 \mathrm{a}), 2.65(1 \mathrm{H}, d d, J=17.0,2.8 \mathrm{~Hz}, \mathrm{H}-3 \mathrm{~b}) ;{ }^{13} \mathrm{C}-\mathrm{NMR}\left(\mathrm{CD}_{3} \mathrm{OD}\right): \delta 192.07$ (CO), 164.86 (C-7), 163.77 (C-8a), 144.96 (C-3'), 144.59 (C-4'), 130.31 (C-1'), 128.74 (CH-5), 118.15 (CH6'), 114.98 (CH-5'), 113.64 (C-4a), 113.21 (CH-2'), 110.65 (CH-6), 102.77 (CH-8), 79.45 (CH-2), $43.62\left(\mathrm{CH}_{2}-3\right)$; EIMS $m / z$ (\% relative intensity): $272\left(\mathrm{M}^{+}, 100\right), 271$ (55), 255 (24), 163 (20), 150 (87), 137 (52), 136 (24) (lit. [17]: $272\left(\mathrm{M}^{+}, 65\right)$ ).

Butein (5). Orange-yellowish needles, m.p. $211-212^{\circ} \mathrm{C}$ (lit. [10]: $\left.214^{\circ} \mathrm{C}\right)$; UV $\lambda_{\max }(\mathrm{MeOH}) \mathrm{nm}(\log \varepsilon)$ : 262 (6.88), 380 (7.04) (lit. [13]: 239sh, 266, 319sh, 379 in methanol); FTIR $v_{\max }\left(\mathrm{KBr}, \mathrm{cm}^{-1}\right): 3546$, $3471,3295,1638,1591,1557,1513,1351,1234,1123 ;{ }^{1} \mathrm{H}-\mathrm{NMR}\left(\mathrm{CD}_{3} \mathrm{OD}\right): \delta 7.81(1 \mathrm{H}, d, J=8.9 \mathrm{~Hz}$, H-6') $7.70(1 \mathrm{H}, d, J=15.3 \mathrm{~Hz}, \mathrm{H}-\beta), 7.40(1 \mathrm{H}, d, J=15.3 \mathrm{~Hz}, \mathrm{H}-\alpha), 7.15(1 \mathrm{H}, d, J=1.8 \mathrm{~Hz}, \mathrm{H}-2)$, $7.05(1 \mathrm{H}, d d, J=8.2,1.8 \mathrm{~Hz}, \mathrm{H}-6), 6.82(1 \mathrm{H}, d, J=8.2 \mathrm{~Hz}, \mathrm{H}-5), 6.40\left(1 \mathrm{H}, d d, J=8.9,2.4 \mathrm{~Hz}, \mathrm{H}-5^{\prime}\right)$, 
$6.33\left(1 \mathrm{H}, d, J=2.4 \mathrm{~Hz}, \mathrm{H}-3^{\prime}\right) ;{ }^{13} \mathrm{C}-\mathrm{NMR}\left(\mathrm{CD}_{3} \mathrm{OD}\right): \delta 191.87(\mathrm{CO}), 165.49\left(\mathrm{C}-2^{\prime}\right), 164.38\left(\mathrm{C}-4^{\prime}\right)$, 147.87 (C-3), 144.83 (C-4), 144.61 (CH- $\beta$ ), 131.56 (CH-6'), 126.78 (C-1), 122.19 (CH-6), 116.86 $(\mathrm{CH}-\alpha), 115.10(\mathrm{CH}-5), 114.28(\mathrm{CH}-2), 113.21\left(\mathrm{C}^{-1}{ }^{\prime}\right), 107.86\left(\mathrm{CH}-5^{\prime}\right), 102.66\left(\mathrm{CH}-3^{\prime}\right)$; EIMS $m / z(\%$ relative intensity): $272\left(\mathrm{M}^{+}, 60\right), 255$ (9), 163 (30), 150 (30), 137 (100), 123 (12), 110 (18).

Biological evaluation: Antimicrobial assay [19]

Antimicrobial activity of the crude extracts and isolates 3-5 was investigated using the agar dilution method [19]. Briefly, the tested compounds dissolved in either $\mathrm{CH}_{2} \mathrm{Cl}_{2}$ or $\mathrm{MeOH}$ were individually mixed with Müller Hinton $(\mathrm{MH})$ broth to obtain a final volume of $2 \mathrm{~mL}$. Two-fold dilution was prepared and the solution was then transferred to the $\mathrm{MH}$ agar solution to yield the final concentrations ranging from 256-4 $\mu \mathrm{g} / \mathrm{mL}$. Twenty seven strains of microorganisms (listed below), cultured in $\mathrm{MH}$ broth at $37^{\circ} \mathrm{C}$ for $24 \mathrm{~h}$, were diluted with $0.9 \%$ normal saline solution to adjust the cell density of $10^{8} \mathrm{CFU} / \mathrm{mL}$.

\begin{abstract}
Gram-negative bacteria
Escherichia coli ATCC 25922

Klebsiella pneumoniae ATCC 700603

Serratia marcescens ATCC 8100

Salmonella typhimurium ATCC 13311

Salmonella choleraesuis ATCC 10708

Shewanella putrefaciens ATCC 8671

Achromobacter xylosoxidans ATCC 2706

Pseudomonas aeruginosa ATCC 15442

Pseudomonas stutzeri ATCC 17587
\end{abstract}

Gram-positive bacteria

Staphylococcus aureus ATCC 29213

Staphylococcus aureus ATCC 25923

Enterococcus faecalis ATCC 29212

Enterococcus faecalis ATCC 33186

Micrococcus lutens ATCC 10240

Bacillus subtilis ATCC 6633

Corynebacterium diphtheriae NCTC 10356

Yeasts

Saccharomyces cereviseae ATCC 2601

Candida albicans ATCC 90028

\author{
Clinical specimens \\ Gram-negative bacteria \\ Shigella dysenteriae \\ Salmonella enteritidis type $C$ \\ Morganella morganii \\ Aeromonas hydrophila \\ Citrobacter freundii \\ Plesiomonas shigelloides
}

Gram-positive bacteria

Streptococcus pyogenes II

Bacillus cereus

Listeria monocytogenes

The organisms were inoculated onto each plate using a multipoint inoculator and further incubated at $37^{\circ} \mathrm{C}$ for $18-48 \mathrm{~h}$. Compounds which possessed high efficacy to inhibit bacterial cell growth were analyzed. 
Antioxidative assay [20, 21]

Two methods were used, DPPH and SOD assays. The antioxidative activity of the crude extracts was elucidated by DPPH radical scavenging assay [20]. When DPPH (a stable purple color) reacts with an antioxidant compound, it is reduced to yield a light-yellow color of diphenylpicrylhydrazine. Changes of the color can be spectrophotometrically measured. In this study, experiment was initiated by preparing $0.2 \mathrm{mM}$ solution of $\mathrm{DPPH}$ in methanol. One $\mathrm{mL}$ of this solution was added sample solution $(1 \mathrm{mg} / \mathrm{mL}$ dissolved in methanol, $0.5 \mathrm{~mL})$. After $30 \mathrm{~min}$, absorbance was measured at $517 \mathrm{~nm}$ and the percentage of radical scavenging activity was calculated from the following equation:

$\%$ Radical scavenging $=(1-$ Abs.sample/Abs.cont $) \times 100$

where Abs.cont is the absorbance of the control reaction and Abs.sample is the absorbance in the presence of sample.

The SOD activity was assayed by measuring inhibition of the photoreduction of nitro blue tetrazolium (NBT) [21]. The indirect assay is comprised of several reactions: the photochemically excited riboflavin was first reduced by methionine into a semiquinone, which donated an electron to oxygen to form the superoxide source. The superoxide readily converted NBT into a purple formazan product. In this regard, the SOD activity was inversely related to the amount of formazan formed.

Cytotoxic assay [22]

Cytotoxic activity was determined by a slightly modified quantitative cytotoxicity assay from other investigators [22]. Briefly, the confluent cell monolayers were trypsinized and diluted with appropriate culture medium to a final concentration of $3 \times 10^{5}$ cells $/ \mathrm{mL}$. Portions $(100 \mu \mathrm{L})$ containing approximately $3 \times 10^{4}$ cells were distributed into 96-well flat-bottomed tissue culture plates and incubated overnight at $37^{\circ} \mathrm{C}$ in a humidified $5 \% \mathrm{CO}_{2}$ incubator. Solutions $(100 \mu \mathrm{L})$ containing different concentrations of tested compounds $3-5(0.001-10 \mu \mathrm{g} / \mathrm{mL})$ or taxol $(0.012-1.2 \mu \mathrm{g} / \mathrm{mL})$ were added to each well and the plates were incubated as above for an additional $48 \mathrm{~h}$. After the incubation, each well was washed (x 3) with phosphate-buffered saline (PBS, pH 7.2) and then stained with crystal violet. After the excess dye was removed, the stained cells were lysed with $100 \mathrm{mM} \mathrm{HCl}$ $(100 \mu \mathrm{L})$ in absolute methanol and the optical density was determined by a microtitre plate reader (Titertek, Multiskan MCC/340) set to read at a wavelength of $540 \mathrm{~nm}$. All tests were carried out in quadruplicate and the mean value was calculated. The activity was expressed as $\mathrm{ED}_{50}$ (the effective dose that inhibits $50 \%$ of cell growth).

\section{Acknowledgements}

We thank the Faculty of Science, Srinakharinwirot University, the Faculty of Medical Technology, Mahidol University, and Chulabhorn Research Institute for facilities and supports. This project was partially supported by the annual budget grant of Mahidol University (B.E. 2551-2555). 


\section{References}

1. Morse, C. Ecology \& Evolutionary Biology Conservatory (Online 2000, 30 March). http://florawww.eeb.uconn.edu/acc_num/198500652.html.

2. Huxley, C. R.; Jebb, M. H. P. The tuberous epiphytes of the rubiaceae 1: A new subtribe-the hydnophytinae. Blumea 1991, 36, 1-20.

3. Smitinund, T. Thai plant names (botanical names-vernacular names); Funny Publishing: Bangkok, 1980; pp. 183-184.

4. Prommee, P. Thai traditional medicine; Mahachulalongkon Publishing: Bangkok, 1988; p. 51.

5. Beckstrom-Sternberg, S. M.; Duke J. A.; Wain K. K. The Ethnobotany Database; (Online 1994, July). http://probe.nal.usda.gov:8300/cgi-bin/webace? $\mathrm{db}=$ ethnobotdb\& class $=$ Taxon\&object= Hydnophytum+formicarium.

6. Nguyen, M. T.; Awale, S.; Tezuka, Y.; Tran, Q. L.; Watanabe, H.; Kadota, S. Xanthine oxidase inhibitory activity of Vietnamese medicinal plants. Biol. Pharm. Bull. 2004, 27, 1414-1421.

7. Ueda, J. Y.; Tezuka, Y.; Banskota, A. H.; Tran, Q. L.; Tran, Q. K.; Hariyama, Y.; Saiki, I.; Kadota, S. Antiproliferative activity of Vietnamese medicinal plants. Biol. Pharm. Bull. 2002, 25, 753-760.

8. Huxley, C. Symbiosis between ants and epiphytes. Biol. Rev. 1980, 55, 321-340.

9. Pouchert, C. J.; Bekke, J. The Aldrich library of ${ }^{13} \mathrm{C}$ and ${ }^{1} H$ FTNMR spectra; Aldrich Chemical Company: Wisconsin, 1993; p. 569.

10. Devon, T. K.; Scott, A. I. Handbook of naturally occurring compounds: acetogenins, shikimates and carbohydrates; Academic Press: New York, 1975; Vol. 1, pp. 10-167.

11. Saitoh, T.; Noguchi, H.; Shibata, S. A new isoflavone and the corresponding isoflavanone of licorice root. Chem. Pharm. Bull. 1978, 26, 144-147.

12. Yenesew, A.; Midiwo, J. O.; Waterman, P. G. Rotenoids, isoflavones and chalcones from the stem bark of Mellettia usaramensis subspecies usaramensis. Phytochemistry 1998, 47, 295-300.

13. Mabry, T. J.; Markham, K. R.; Thomas, M. B. The systematic identification of flavonoids; Springer-Verlag: New York, 1970; pp. 165-166.

14. Kuroyanagi, M.; Fukuoka, M.; Yoshihira, K; Natori, S. Chemical and toxicology studies on bracken fern, Pteridium aquilinum var. latiusculum. III. Further characterization of pterosins and pterosides, sesquiterpenes and the glucosides having 1-indanone skeleton, from the rhizomes. Chem. Pharm. Bull. 1979, 27, 592-601.

15. Hata, K.; Baba, K; Kozawa, M. Chemical studies on the heartwood of Cassia garrettiana CRAIB. II. nonanthraquinonic constituents. Chem. Pharm. Bull. 1979, 27, 984-989.

16. Santavy', F.; Walterova', D.; Hruban, L. Ultraviolet spectra, methoxy and methylenedioxy groups of some aromatic compounds and alkaloids. IV; The effect of hydroxyl, methoxyl and methylenedioxy groups on the ultraviolet spectra of aromatic compounds conjugated with an oxogroup or with and $\alpha, \beta$-double bond in the side chain. Coll.t Czech. Chem. Commun. 1970, 37, 1825-1850.

17. Van der Westhuizen, J. H.; Ferreira, D.; Roux, D. G. Photochemical deoxygenation of an $\alpha$-ketol: The dihydroflavonol-flavanone conversion. J. Chem. Soc. Perkin Trans I. 1980, 1003-1006. 
18. Roux, D. G.; Paulus, E. Condensed tannins. 10. Isolation of (-)-butin and butein from wattle heartwoods. Biochem. J. 1961, 80, 62-63.

19. Baron, E. J.; Peterson, L. R.; Finegold, S. M. Methods for testing antimicrobial effectiveness; In Bailey and Scott's diagnostic microbiology; Mosby-Year Book: St. Louis, MI, 1994; pp. 168-193.

20. Yen, G. C.; Hsieh, G. C. Antioxidant effects on dopamine and related compounds. Biosci. Biotechnol. Biochem. 1997, 61, 1646-1649.

21. Piacham T.; Isarankura-Na-Ayudhya C.; Nantasenamat C.; Yainoy S.; Ye L.; Prachayasittikul V. Metalloantibiotic $\mathrm{Mn}(\mathrm{II})$-bacitracin complex mimicking manganese superoxide dismutase. Biochem. Biophys. Res. Comm. 2006, 341, 925-930.

22. Tengchaisri, T.; Chawengkirttikul, R.; Rachaphaew, N.; Reutrakul, V.; Sangsuwan, R.; Sirisinha, S. Antitumor activity of triptolide against cholangiocarcinoma growth in vitro and in hamsters. Cancer Lett. 1998, 133, 169-175.

23. Bate-Smith, E. C.; Swain, T. The isolation of 2,4,4'-trihydroxychalcone from yellow varieties of Dahlia variabilis. J. Chem. Soc. 1953, 2185-2187.

24. Vaya, J.; Belinky, P. A.; Aviram, M. Antioxidant constituents from licorice roots: isolation, structure elucidation and antioxidative capacity toward LDL oxidation. Free Radic. Biol. Med. 1997, 23, 302-313.

25. Kong, L. D.; Zhang, Y.; Pan, X.; Tan, R. X.; Cheng, C. H. Inhibition of xanthine oxidase by liquiritigenin and isoliquiritigenin isolated from Sinofranchetia chinensis. Cell. Mol. Life Sci. 2000, 57, 500-505.

26. Zheng, Z.-P.; Cheng, K.-W.; Chao, J.; Wu, J.; Wang, M. Tyrosinase inhibitors from paper mulberry (Broussonetia papyrifera). Food Chem. 2008, 106, 529-535.

27. Hayashi, H.; Hiraoka, N.; Ikeshiro, Y.; Yamamoto, H. Organ specific localization of flavonoids in Glycyrrhiza glabra L. Plant Sci. 1996, 116, 233-238.

28. Wegener, J. W.; Nawrath, H. Cardiac effects of isoliquiritigenin. Eur. J. Pharmacol. 1997, 326, $37-44$.

29. Wegener, J. W.; Nawrath, H. Differential effects of isoliquiritigenin and YC-1 in rat aortic smooth muscle. Eur. J. Pharmacol. 1997, 323, 89-91.

30. Tawata, M.; Aida, K.; Noguchi, T.; Ozaki, Y.; Kume, S.; Sasaki, H.; Chin, M.; Onaya, T. Antiplatelet action of isoliquiritigenin, an aldose reductase inhibitor in licorice. Eur. J. Pharmacol. 1992, 212, 87-92.

31. Yu, S. M.; Kuo, S. C. Vasorelaxant effect of isoliquiritigenin, a novel soluble guanylate cyclase activator, in rat aorta. Br. J. Pharmacol. 1995, 114, 1587-1594.

32. Haraguchi, H.; Ishikawa, H.; Mizutani, K.; Tamura, Y.; Kinoshita, T. Antioxidative and superoxide scavenging activities of retrochalcones in Glycyrrhiza inflata. Bioorg. Med. Chem. 1998, 6, 339-347.

33. Kobayashi, S.; Miyamoto, T.; Kimura, I.; Kimura, M. Inhibitory effect of isoliquiritigenin, a compound in licorice root, on angiogenesis in vivo and tube formation in vitro. Biol. Pharm. Bull. 1995, 18, 1382-1386.

34. Hsu, Y.-L.; Kuo, P.-L.; Lin, C.-C. Isoliquiritigenin induces apoptosis and cell cycle arrest through p53-dependent pathway in Hep G2 cells. Life Sci. 2005, 77, 279-292. 
35. Kuma, S.; Sharma, A.; Madan, B.; Singhal, V.; Ghosh, B. Isoliquiritigenin inhibits IkB kinase activity and ROS generation to block TNF- $\alpha$ induced expression of cell adhesion molecules on human endothelial cells. Biochem. Pharmacol. 2007, 73, 1602-1612.

36. Takahashi, T.; Takasuka, N.; Iigo, M.; Baba, M.; Nishino, H.; Tsuda, H.; Okuyama, T. Isoliquiritigenin, a flavonoid from licorice, reduces prostaglandin E2 and nitric oxide, causes apoptosis, and suppresses aberrant crypt foci development. Cancer Sci. 2004, 95, 448-453.

37. Jung, J. I.; Chung, E.; Seon, M. R.; Shin, H.-K.; Kim, E. J.; Lim, S. S.; Chung, W.-Y.; Park, K.K.; Park J. H. Y. Isoliquiritigenin (ISL) inhihits ErbB3 signaling in prostate cancer cells. BioFactors 2006, 28, 159-168.

38. Figueiredo, A. R.; Campos, F.; de Freitas, V.; Hogg, T.; Couto, J. A. Effect of phenolic aldehydes and flavonoids on growth and inactivation of Oenococcus oeni and Lactobacillus hilgardii. Food Microbiol. 2008, 25, 105-112.

39. Martin, T. S.; Kikuzaki, H.; Hisamoto, M.; Nakatani, N. Constituents of Amomum tsao-ko and their radical scavenging and antioxidant activities. J. Am. Oil Chem. Soc. 2000, 77, 667-673.

40. Lee, T. Y.; Chang, H. H.; Wang, G. J.; Chiu, J. H.; Yang, Y. Y.; Lin, H. C. Water-soluble extract of Salvia miltiorrhiza ameliorates carbon tetrachloride-mediated hepatic apoptosis in rats. J. Pharm. Pharmacol. 2006, 58, 659-665.

41. Lu, Y.; Yeap, F. L. Salvianolic acid L, a potent phenolic antioxidant from Salvia officinalis. Tetrahedron Lett. 2001, 42, 8223-8225.

42. Lee, S.; Shim, S. H.; Kim, J. S.; Shin, K. H.; Kang, S. S. Aldose reductase inhibitors from the fruiting bodies of Ganoderma applanatum. Biol. Pharm. Bull. 2005, 28, 1103-1105.

43. Shibata, M.-A.; Hirose, M.; Yamada, M.; Tatematsu, M.; Uwagawa, S.; Ito, N. Epithelial cell proliferation in rat forestomach and glandular stomach mucosa induced by catechol and analogous dihydroxybenzenes. Carcinogenesis 1990, 11, 997-1000.

44. Kim, Y. S.; Kim, N. H.; Lee, S. W.; Lee, Y. M.; Jang, D. S.; Kim, J. S. Effect of protocatechualdehyde on receptor for advanced glycation end products and TGF- $\beta 1$ expression in human lens epithelial cells cultured under diabetic conditions an on lens opacity in streptozotocin-diabetic rats. Eur. J. Pharmacol. 2007, 569, 171-179.

45. Lai, P. K.; Oh-Hara, T.; Tamura, Y.; Kawazoe, Y.; Konno, K.; Sakagami, H.; Tanaka, A.; Nonoyama, M. Polymeric phenylpropenoids are the active components in the pine cone extract that inhibit the replication of type-1 human immunodeficiency virus in vitro. J. Gen. Appl. Microbiol. 1992, 38, 303-312.

46. Bhargava, S. K. Estrogenic and postcoital anticonceptive activity in rats of butin isolated from Butea monosperma seed. J. Ethnopharmacol. 1986, 18, 95-101.

47. Lee, M.-H.; Lin, Y.-P.; Hsu, F.-L.; Zhan, G.-R.; Yen, K.-Y. Bioactive constituents of Spatholobus suberectus in regulating tyrosinase-related proteins and mRNA in HEMn cells. Phytochemistry 2006, 67, 1262-1270.

48. Perkin F. R. S., A. G.; Hummel, J. J. CXLVII.-The colouring principle of the flowers of the Butea Frondosa. J. Chem. Soc. Trans. 1904, 85, 1459-1472.

49. Shimokoriyama, M.; Geissman, T. A. Anthochlor pigments. XIV. The pigments of Viguiera multiflora (Nutt.) and Baeria chrysostoma (F. and M.). J. Org. Chem. 1960, 25, 1956-1959. 
50. Geissman, T. A. Anthochlor pigments. III. The pigments of Cosmos sulphureus. J. Chem. Soc. 1942, 64, 1704-1707.

51. Geissman, T. A; Harborne, J. B.; Seikel, M. K. Anthochlor pigments. XI. The Constituents of Coreopsis maritima. Reinvestigation of Coreopsis gigantea. J. Am. Chem. Soc. 1956, 78, 825829.

52. Cheng, Z.-J.; Kuo, S.-C.; Chan, S.-C.; Ko, F.-N.; Teng, C.-M. Antioxidant properties of butein isolated from Dalbergia odorifera. Biochim. Biophys. Acta. 1998, 1392, 291-299.

53. Chan, S. C.; Chang, Y. S.; Wang, J. P.; Chen, S. C.; Kuo, S. C. Three new flavonoids and antiallergic, anti-inflammatory constituents from the heartwood of Dalbergia odorifera. Planta Med. 1998, 64, 153-158.

54. Sogawa, S.; Nihro, Y.; Ueda, H.; Miki, T.; Matsumoto, H.; Satoh, T. Protective effects of hydroxychalcones on free radical-induced cell damage. Biol. Pharm. Bull. 1994, 17, 251-256.

55. Lee, J. C.; Lim, K. T.; Jang, Y. S. Identification of Rhus verniciflua stokes compounds that exhibit free radical scavenging and anti-apoptotic properties. Biochim. Biophys. Acta. 2002, 1570, 181-191.

56. Chen, W.-J.; Song, J.-R.; Guo, P.; Wen, Z.-Y. Butein, a more effective antioxidant than $\alpha-$ tocopherol. J. Mol. Struct. THEOCHEM 2006, 763, 161-164.

57. Lee, S. H.; Seo, G. S.; Sohn, D. H. Inhibition of lipopolysaccharide-induced expression of inducible nitric oxide synthase by butein in RAW264.7 cells. Biochem. Biophys. Res. Comm. 2004, 323, 125-132.

58. Lee, S. H.; Seo, G. S.; Jin, X. Y.; Ko, G.; Sohn, D. H. Butein blocks tumor necrosis factor $\alpha-$ induced interleukin 8 and matrix metalloproteinase 7 production by inhibiting p38 kinase and osteopontin mediated signaling events in HT-29 cells. Life Sci. 2007, 81, 1535-1543.

59. Wang, Y.; Chan, F. L.; Chen, S.; Leung, L. K. The plant polyphenol butein inhibits testosteroneinduced proliferation in breast cancer cells expressing aromatase. Life Sci. 2005, 77, 39-51.

60. Yu, S. M.; Cheng, Z. J.; Kuo, S. C. Endothelium-dependent relaxation of rat aorta by butein, a novel cyclic AMP-specific phosphodiesterase inhibitor. Eur. J. Pharmacol. 1995, 280, 69-77.

61. Kang, D. G.; Kim, Y. C.; Sohn, E. J.; Lee, Y. M.; Lee, A. S.; Yin, M. H.; Lee, H. S. Hypotensive effect of butein via the inhibition of angiotensin converting enzyme. Biol. Pharm. Bull. 2003, 26, 1345-1347.

62. Hayashi, K.; Nagamatsu, T.; Honda, S.; Sukuki, Y. Butein $\left(3,4,2^{\prime}, 4^{\prime}\right.$-tetrahydroxychalcone) ameliorates experimental anti-glomerular basement membrane antibody-associated glomerulonephritis. Eur J. Pharmacol. 1996, 316, 297-306.

63. Kim, N. Y.; Pae, H. O.; Oh, G. S.; Kang, T. H.; Kim, Y. C.; Rhew, H. Y.; Chung, H. T. Butein, a plant polyphenol, induces apoptosis concomitant with increased caspase-3 activity, decreased Bcl-2 expression and increased Bax expression in HL-60 cells. Pharmacol. Toxicol. 2001, 88, 261-266.

64. Iwashita, K.; Kobori, M.; Yamaki, K.; Tsushida, T. Flavonoids inhibit cell growth and induce apoptosis in B16 melanoma 4A5 cells. Biosci. Biotechnol. Biochem. 2000, 64, 1813-1820.

65. Hung, C.-Y.; Yen, G.-C. Extraction and identification of antioxidative components of Hsian-tsao (Mesona procumbens Hems1.). Lebensm.-Wiss. u.-Technol. 2001, 34, 306-311. 
66. Ramadan, M. F.; Zayed, R.; El-Shamy, H. Screening of bioactive lipids and radical scavenging potential of some solanaceae plants. Food Chem. 2007, 103, 885-890.

67. Batta, A. K.; Xu, G.; Honda, A.; Miyazaki, T.; Salen, G. Stigmasterol reduces plasma cholesterol levels and inhibits hepatic synthesis and intestinal absorption in the rat. Metabolism 2006, 55, 292-299.

Sample Availability: Contact the authors.

(C) 2008 by MDPI (http://www.mdpi.org). Reproduction is permitted for noncommercial purposes. 